\title{
Opinion
}

\section{A Perspective on Working in Hospice and Grief}

\author{
Lindsey Ingle, BSc* \\ Hospice Care Consultant/Hospice Educator, Kindred Hospice, Lenexa, Kansas, USA \\ *Corresponding author \\ Lindsey Ingle, BSc \\ Hospice Care Consultant/Hospice Educator, Kindred Hospice, Lenexa, Kansas, USA; E-mail: Linz66213@yahoo.com
}

Article information

Received: September 9 ${ }^{\text {th }}, 2020$; Accepted: September 23 ${ }^{\text {rd }}, 2020$; Published: October $3^{\text {rd }}, 2020$

\section{Cite this article}

SIngle L. A perspective on working in hospice and grief. Palliat Med Hosp Care Open J. 2020; 6(2): 15. doi: I0.17। 40/PMHCOJ-6-I37

\begin{abstract}
$A^{1}$ lmost every time that I share my profession with others, I am met with a myriad of facial expressions and awkward gestures that reflect a sort of discomfort and general misunderstanding about what I do. The only common thread in public perception seems to be that it's hard and terribly sad. Hard in the sense that it takes a very special and different human being to stare death in the face every day and be able to cope, understand and deal with the cycle of life and to be able to stay focused and strong for other families.
\end{abstract}

Most of my friends greet me with things like, "I don't know how you do that job?" or "I could never do what you do." Or even, "bow do you not cry every single day??' I have to be honest that when I meet with families in their darkest of hours, there is a self-preparation that goes a long with it. There is a mental shell that I place myself in. I understand that when I push open the door and walk into a hospital room filled with emotions and uncertainty, that I have the ability to be the light. I am there to guide them and give answers to questions to the best of my ability. Questions that are dark and intense. Questions that evoke tears and strike pain. Sometimes its questions that I myself do not have the ability to answer such as time frames. If only we all had a crystal ball. That shell I placed myself in allows me to be capable of being there to comfort these families in there time of need. I know that their grief is not my grief. I know that their journey is not my own. There is a disconnect that happens. It's a purposeful disconnect, because I am not there to add to their discomfort. I am there in hopes that for a moment, I can take a piece of it away. There is a stigma that because we work with death every day, that we become desensitized to it. We don't. It's an unusual normal that hospice providers work in. It's known that the services we render provide an enormous amount of relief, and in that we become okay with seeing death and living through death every day. It's known that we were there for a patient that was in an immense amount of pain, and we provided comfort. It's knowing that the paperwork and the preparation for death for a daughter that lives states away is completed because we were able to step in with a clear mind and get it done for her. It's known that the job we do and the service to these families is bigger and goes beyond the death itself.

But in all of that, I know that myself and every single consultant/nurse/chaplain/social worker that I have worked alongside of, has had their moment. It's typically in a car in the back of a parking lot, or in an office behind a closed door. We share in your grief. We feel your loss. We understand that the world just lost a special person. We feel it and we allow ourselves to feel it. Sometimes when we have really become part of your family, we feel it in your presence, while holding your hand and we get to feel it with you.

I have felt the gravity of losing a parent. I feel it everyday. The words and kindness of my Mother's hospice nurses are still there six years after her death. I can see their faces in my mind, I can feel the comfort of their words and the guidance that they provided. Those words and those faces are what changed my course to be able to do the same for others going through this journey. So when I am greeted with "How can you do that job?" my response is "How could I not?" "If not me then whom?" Death is scary, death is sad, death is unknown. But death should be as beautiful as birth. A life should be as respected upon departure as it was upon arrival. To think that the words I have said in someone's time of need will ring true years after their loved one is gone, is the best gift I could ever give someone. 